\title{
Omówienia
}

DOI: $10.14746 /$ por.2019.1.28

\section{WŚRÓD PORÓWNAŃ I ANALOGII}

\author{
ELIZA KĄCKA ${ }^{1}$
}

Siwiec Magdalena, red. O Norwidzie komparatystycznie. Kraków: Wydawnictwo Uniwersytetu Jagiellońskiego, 2019. $470 \mathrm{~S}$.

W przedmowie do małej antologii wierszy i komentarzy Cyprian Norwid. Klucze od Echa napisałam niedawno, że osobowość autora Pieśni społecznej stron czterech przejawia się jako osobność, stąd nie ma dziś ważniejszych nad jego dziełem badań nad komparatystyczne, które tę osobność określą i nazwą (Kącka 9-13). I proszę: wydany właśnie zbiór dwudziestu studiów O Norwidzie komparatystycznie pod redakcją Magdaleny Siwiec spełnia ten postulat. Jako że osobność wyraża się przez swoje przeciwieństwo... Ta myśl spodobałaby się Norwidowi.

Z lektury trudno nie wynieść przekonania, że autor Promethidiona doskonale zdawał sobie sprawę, iż nie chce i nie potrafi być taki jak inni - ci wielcy poezji polskiej, którzy go bezpośrednio poprzedzili - i że wypada mu szukać własnej drogi. Innymi słowy: że jest, jak oni, poetą pielgrzymem, lecz zmierza gdzie indziej. Nim więc stał się autorem znaczącym, był już rewizjonistą. I do końca nim został, płacąc za to cenę potężną, którą zresztą przewidział. Zbiór O Norwidzie komparatystycznie drogę tę wykreśla, lecz - jak to wielogłos - nie wskazuje ściśle jej celu. Zanim więc przyjrzę się zawartości książki, pozwolę sobie przedstawić własny punkt widzenia $\mathrm{w}$ tej kwestii, zaiste fundamentalnej. Wychodząc $\mathrm{z}$ tego punktu, będę bowiem referować wielce różnorodne i wnikliwe dokonania autorów książki. Otóż ta moja hipoteza czy domysł, o których mowa, zrodziły się przed laty nad esejem Zdzisława Łapińskiego $O$ „Czułości”. Kilka przypisów do Gomulickiego (Łapiński), gdzie autor jak najsłuszniej stara się ustalić treść Norwidowskiego tytułowego pojęcia. Wśród wielu słownikowych znaczeń pomija jednak jedno, najmniej może leksykograficznie oczywiste, za to obejmujące wszystkie sensy utworu. I nie tylko obejmujące, lecz i nadające mu nową generalną wymowę. Jest to pojęcie ekspresji. Czułość to wiersz

1 E-mail: eliza.kacka@gmail.com 
liryczny przedstawiający w rewelacyjny sposób dynamikę, a ściślej - fenomenologię ekspresji. I właśnie kwestia wyrazu mogła, jak sądzę, stać się dla Norwida tą dźwignią, która pozwoliła mu ruszyć z miejsca gmach zastanej poezji, i która stała się dlań podstawą właściwej mu poetyckiej antropologii. Jakimi środkami człowiek współczesny świadomie i nieświadomie wyraża siebie i jakimi sposobami świat dookolny wraża się weń i go uraża - oto refleksja, którą myśl Norwida nadgryza rzeczywistość. Skupienie uwagi na tej sprawie: źródeł oraz ekonomiki, wzajemnej wymiany ekspresji, kosztowało poetę osobność.

Zbiór O Norwidzie komparatystycznie składa się z czterech części: Twórczość Norwida w kontekście prąów intelektualnych epoki; Norwid a twórcy epoki; Twórczość Norwida wobec muzyki i sztuk wizualnych; Norwid wobec tradycji i Norwid w przekładach. Dość niespodziewanie na prowadzenie $\mathrm{w}$ randze problemowej wychodzi część druga. Istotnie komparatystyczny wymiar mają tam bowiem dwa studia: redaktorki tomu, pt. Norwid - Baudelaire: profanacje (Siwiec) oraz Łukasza Niewczasa Norwid - parnasista? (Niewczas). Każde z nich ustosunkowuje się mianowicie do jednego z zasadniczych pytań, jakie nastręcza dzieło Norwida: czyżby istotnie było tak, jak się pobieżnemu spojrzeniu przedstawia, że między twórczością poety polskiego (i szerzej - całego środowiska emigracyjnych poetów polskich) a otaczającym go żywiołem literatury francuskiej nie było żadnych istotnych związków? Czy w rzeczy samej Norwid - poza Victorem Hugo i Julesem Micheletem - na nikogo nie zwrócił uwagi? Jak to możliwe? W tle majaczy, ma się rozumieć, śmiała, o ile nie nazbyt śmiała hipoteza sprzed lat Juliusza Wiktora Gomulickiego, iż Norwid komponował cykl Vade-mecum z myślą i w rozmyślnej opozycji do Baudelaire'owskich Kwiatów zła, oraz - też sprzed lat sześćdziesięciu - rozpoznania Macieja Żurowskiego związków stylistyki Norwidowskiej z Théophile'em Gautierem (Żurowski 2007). W obydwu przypadkach szło o włączenie Norwida w kontekst europejski, poezji polskiej w międzynarodową siatkę przednowoczesnych idei.

Magdalena Siwiec nie posuwa się tak daleko, lecz konfrontację Norwida z Baudelaire'em uważa za uprawnioną. Więcej: odtwarza dwustuletnią bez mała więź ideową twórców bezsprzecznie przełomowych, acz w swych poglądach jawnie zachowawczych. Powołując się na książkę Antoine'a Compagnona Les antimodernes de Joseph de Maistre à Roland Barthes (2005), nadaje takim postaciom jak François-René de Chateaubriand, Charles Baudelaire, Gustave Flaubert, Marcel Proust, Roger Caillois i Emil Cioran etykietkę amodern (przeciwstawiającą ich zarówno nowatorom - modern, jak i retrogradom - antimodern). Na tym gruncie istotnie wykryć można analogie postaw Baudelaire'a i Norwida. Obaj rówieśnicy (trzecim jest - do kompletu - Fiodor Dostojewski) konstatują w swym dziele zakłócenie antytezy sacrum i profanum, co wymaga nowej, paradoksalnej nieufności wobec tak zwanego wiecznego piękna. Siwiec wyzyskuje tu znakomicie korespondencję między Baudelaire' owskimi przypowieściami o utracie przez poetę aureoli (w wierszu Bénédiction i jednym z małych poematów prozą) a desakralizacją piękna, którą wyczytać można 
z finałów Fortepianu Szopena i Quidama, a zwłaszcza - co odkrywcze! - opowieści Bransoletka. Jej tytułowy rekwizyt to przecież także upadła aureola, „zataczająca się w błocie", jak mówi wiersz Larwa. W tej ostatniej kwestii chętnie ofiaruję Siwiec jeszcze jedną przesłankę, że Norwid myślał równolegle z Baudelaire'em. Otóż, jak pamiętamy, w rozdzierającej Jesieni Norwida przychodzi poecie wielkomiejskie „błoto deptać, ile z łez to błoto" (Norwid), zaś u Baudelaire'a w wierszu Moesta et errabunda, o ile wiem, późniejszym, poecie marzy się ucieczka: „Emporte-moi, wagon! enlève-moi, frégate! / Loin, loin! ici la boue est faite de nos pleurs!" (Zabieraj mnie, powozie! Unoś mnie, fregato! Hen! Hen! Tutaj powstają od łez naszych błota!) (Baudelaire 1927: 80; Baudelaire 2018: 197). I pomyśleć, że dwaj dzielący tę samą myśl poeci mijali się na ulicy i nigdy się nie poznali!

Baudelaire to postać tak ważna, że chcę poświęcić mu jeszcze parę słów. Siwiec przywołuje oczywiście jeden ze programowych wierszy Kwiatów..., À une passante, przykład epifanii, jak pisze, zastąpionej przez „doświadczenie chwilowe, przebłysk, który zjawia się i znika tak szybko, jak się pojawił, nie pozostawiając nic poza tęsknotą i marzeniem" (Siwiec 135). Poświęca mu jednak za mało uwagi. Jakaż to ulica ogłuszająco dudni wokół poety? Z pewnością paryskie bulwary. Jakaż kobieta strojna, o efektownej urodzie, może pod wieczór przemierzać je sama? Kobieta publiczna. I oto pomiędzy nim a nią zawiązuje się błyskawiczna wymiana spojrzeń. Nie pada żadne słowo. On wie, z kim ma do czynienia: z pięknem upadłym. Ona wie, że on wie, a jednak ją podziwia, i jest mu za to wdzięczna. Lecz spójrzmy na jego postawę w obliczu posągowej niewiasty: jest "crispé comme extravagant", jak w takich sytuacjach bohater grafik Schulza, „skurczony niby szaleniec”. Bo nie ma na nią pieniędzy i wie, że od jednego rzutu oka ona wie to także. To musi boleć. Tak komunikują się ze sobą dwa wyrzutki społeczeństwa: przechodząca, kobieta wyklęta, i Poeta - wiadomo, przeklęty. Ta epifania to antyepifania, jedna z tych profanacji, o których pisze Siwiec. Chwila, gdy w głębi pohańbienia zakwita na moment Piękno i wzór odnowionej ekspresji, streszczonej do wymiany póz i spojrzeń, do tej ekonomii wyrazu, jaką odkrywał i eksplorował Norwid.

W przeciwieństwie do tych spostrzeżeń, których można i trzeba poczynić jeszcze wiele, Łukasz Niewczas zaczyna od katastrofy. Otóż dzięki odnalezieniu autografu okazało się w sposób niezbity, że wiersz Norwida $W$ albumie, tak niezwykle przypominający Nostalgies d'obélisques Gautiera z Emalii i kamei, jest od nich pięć lat młodszy (1851). Cała misterna konstrukcja Macieja Żurowskiego runęła w jednej chwili. Jak widać, koncept, że ustawiony w 1831 roku po wielkich mozołach na Placu Zgody egipski obelisk tęskni za swym bliźniakiem z Luksoru (i odwrotnie), zaliczał się do pomysłów obiegowych. Niewczas jednak na tym nie poprzestaje. Formułuje druzgocącą dla perspektyw porównawczych tezę, iż nie przypadkiem

brak w pismach Norwida nazwisk Gautiera, Baudelaire'a, Stéphane'a Mallarmégo, Artura Rimbauda, Paula Verlaine'a i innych rewelatorów poezji europejskiej drugiej po- 
łowy XIX wieku. Brak punktu zaczepienia, który pozwoliłby potwierdzić, że Norwid rzeczywiście znał tę twórczość, czytał ją, przemyślał i że mogłaby go ona zainspirować. Jest to istotnie frustrujące, bo trudno przypuszczać, że autor tak zaangażowany w sferę umysłową i kulturalną jak Norwid, przeżywszy niemal pół życia w mieście będącym centrum światowej kultury, zignorował całkowicie rodzącą się na jego oczach nowoczesną poezję europejską. Mimo to dowodów, że nie zignorował - brak, a pokusie modernizowania Norwida przeciwstawia się fakt, że kiedy pisze on o swoim miejscu we współczesnej poezji, układ odniesienia, choć krytyczny, stanowi głównie polski romantyzm (Niewczas 166-167).

Zaiste, Paryż zdawać się mógł mu pustynią nie mniej niż przez dziesiątki lat długowiecznemu Józefowi Bohdanowi Zaleskiemu, co przejmująco opisuje w omawianej książce Elżbieta Nowicka. Tak po stu latach dociekań wygląda ostatnie słowo nauki, wobec czego komparatystyka, acz nadal godna uprawiania, poniekąd staje się czymś innym.

Na pociechę Niewczas wskazuje na ewentualne parnasistowskie filiacje Felicjana Faleńskiego, lecz gdzież temu miłemu poecie do Norwida! Rozpatruje też rolę rzeźby w imaginarium parnasistów oraz Norwida, który uprawiał ją naprawdę. Rzeźba jednak - to myśl zmineralizowana, niezdolna do dialogu. Przy okazji: autor nazbyt zawierzył przenośnym sensom przekładu Langego wiersza Gautiera L'art. Nakazuje on nie paprać się w gipsie, lecz borykać z marmurem karraryjskim czy twardszym i rzadszym - paroskim; artyści w nich pracujący stają się strażnikami czystego konturu, „[les] gardiens du contour pur”. Lange tłumaczy poprawnie: „Straż nieskazitelnych konturów”, lecz Niewczas opatruje to komentarzem: „Rzeźba staje się więc niezwykle dogodnym symbolem artystycznego piękna (także piękna poetyckiego) ze względu na swoją trwałość. [...] Nie dotyka jej czas" (Niewczas 174). Jednakże czysty kontur to coś innego - termin techniczny związany z faktem, iż rzeźbę wolnostojącą można oglądać ze wszystkich stron. A zatem żaden jej obrys nie może być przypadkowy, każdy winien być harmonijny. I właśnie o to chodzi. Jako dowód przywołać można pomnik cesarza Karola IV na placu Krzyżackim w Pradze. Ów seryjny odlew norymberski, erygowany w roku 1848, dzierży w dłoni zwinięty w rulon akt erekcyjny Uniwersytetu Karola, wskutek czego widziany z boku władca zdaje się oddawać czynności wielce nieprzystojnej. Przewodnik Pascala podaje ściśle miejsce, w którym należy stanąć, by uzyskać ten efekt.

Ma się rozumieć, badania komparatystyczne odzyskać by mogły w przypadku Norwida swą wagę w sferze historii idei. Często jest to jednak komparatystyka apofatyczna, czyli wnioskująca z braku związków. Taką niezaszłość rekonstruuje wzorowo Arent van Nieukerken w rozprawie Norwid i scjentyzm - konteksty komparatystyczne (Nieukerken) ze wskazaniem na idee Comte'a i Proudhona. Należy jednak zaraz na wstępie zastrzec, iż Norwid inicjuje w kulturze polskiej znamienną dla niej linię artystów-myślicieli programowo niezgodnych co do niczego z nikim. Rosjanie 
zwą to samodurstwem. Taki miał się okazać w pół wieku później Wyspiański, takimi w znacznej mierze Brzozowski, Irzykowski, Witkacy czy Gombrowicz. Mickiewicz nie znosił Słowackiego, Słowacki - Chopina, a Krasiński - żadnego z nich. Niemniej formacja wielkich romantyków miała swoje autorytety, choćby pośród mistyków. Natomiast Norwid, prócz wielkich artystów przeszłości, nie uznawał nikogo. Toteż jeśli czytywał Comte'a, to w postaci wyciągów na łamach „La Revue des Deux Mondes" (Ho, ho! Uczeni jako nowi święci!), jeśli Proudhona - to kartkując (ze wstrętem) na straganach bukinistów jego liczne broszurki. Rzecz jasna, odnosił się do pojęcia postępu, do ubóstwienia nauki, do socjalizmu i hasła „Własność jest kradzieżą". Jednak doktryny Comte'a i Proudhona służyły polskiemu poecie raczej do satyrycznych parafraz - lecz tych akurat praca van Nieukerkena nie uwzględnia. Podobne wyniki przynosi studium Michała Kuziaka Norwid - Marks. Dwie nowoczesności (Kuziak). Mimo znacznie subtelniejszych wnioskowań (Norwid znał przecież świetnie zjawisko alienacji) paralela rozbija się o twarde słowa z Epilogu Promethidiona: „Końcem końców, praca z grzechu jest” (Norwid 2011: 136). Aż zacytować chce się Fraszkę (I): „Koniec rozmowy”.

Rzecz ciekawa, iż w refleksji filozoficznej Norwida (z nauk uznawał właściwie tylko historyczne) kluczową rolę odgrywa namysł nad zagadnieniami uchwyconymi przez świeżo wówczas wynalezione pojęcia, których jednak nie używał: utylitaryzm (inwencja Milla), organiczność (inwencja Schellinga) i pesymizm (inwencja Schopenhauera). Pojęcia te przydatne być mogły w rozmowie, jaką pośrednio, wedle Sławomira Rzepczyńskiego (tekst Norwod, Czadajew i problem europeizacji Rosji) (Rzepczyński), toczył Norwid z rosyjskim historiozofem i pierwszym nowoczesnym dysydentem Piotrem Czaadajewem. Jednak praca Norwid, Czaadajew i problem europeizacji Rosji ujmuje myśli Rosjanina wiele dramatyzmu. W istocie pierwszy List filozoficzny, ogłoszony w rosyjskim przekładzie z francuskiego w Moskwie przez niedopatrzenie cenzury, był najważniejszą z debat, jakie na temat Rosji kiedykolwiek odbyto. Skąd wywiódł były huzar swoje niebłagonadiożne poglądy, jest wciąż zagadką. Był wolnomularzem, dziedzicem francuskich „ideologów” w rodzaju de Bonalda, a więc millenarystą; ludzkość w swoim rozwoju zmierza dlań do Stwórcy tym szybciej, im bardziej świadomie wypełnia plan boży. Dążenie to ma jednak skazę: naród sabotujący ów plan jako organizm zbiorowy, jako instytucja państwowa i jako społeczność chrześcijańska. „Samotni w świecie, nic nie daliśmy światu, niczego nie nauczyliśmy go; nie wnieśliśmy żadnej idei do masy idei ludzkich, niczym nie przyczyniliśmy się do postępu ludzkiego, a to, co dał nam ten postęp, wypaczyliśmy". Straszliwe te poglądy Czaadajew kolportował ustnie na długo przed publikacją: znał je Puszkin, od Puszkina poznał Mickiewicz, od Mickiewicza de Custine, odeń zaś legion sowietologów XX wieku z Leopoldem Łabędziem na czele.

Mickiewicz miał dla Rosji niepozbawioną tonu pogardy litość (III część Dziadów: Ustęp); Słowacki - zjadliwą ironię (VII Pieśn Beniowskiego), Krasiński wściekłą nienawiść (Memoriat dla Napoleona III). Koncyliacyjne stanowisko Norwida bliższe 
bywa kolejnym Listom Czaadajewa, dostępnym w wydaniach ówczesnej rosyjskiej emigracji. Rzepczyński dorzuca jednak myśl, że drogę Czaadajewa odbył także w stosunku do własnych rodaków Norwid: oba narody wpadły w czarną dziurę i ich powrót na szlak historii pozytywnej przesądzi o przyszłości świata. W każdym razie musieli się mierzyć z podobnymi zarzutami o brak patriotyzmu.

Dalej znajdują się w tomie O Norwidzie komparatystycznie rozprawy, które prędzej można zwać esejami, w swoim rodzaju znakomite choć niezbyt komparatystyczne. W pierwszej części jest to Agnieszki Ziołowicz W żywiole towarzyskości. Arkana Norwidowskiej rozmowy (Ziołowicz), gdzie na podstawie świadectw zawartych w XI tomie Pism wszystkich edycji Gomulickiego odtworzony zostaje, by tak rzec, portret oralny poety. Jest to wizerunek nadspodziewanie żywy, ciepły i serdeczny. Z przytoczeń i komentarzy wyłania się mistrz salonowej konwersacji, który zadziwia oryginalnością, nie dostrzegając chwili, w której zaczyna nią rozmówców płoszyć. Jeszcze przyznają mu niektórzy dar fascynującego monologu, lecz z biegiem lat owa „sytuacja komunikacyjna” przeradza się w dramat. „Z duszą swą nosił się pomiędzy ludźmi jako z numizmatem rzadkim, nikomu nie znanym, nikomu niepotrzebnym, do niczego nieprzydatnym" - podsumowuje ten etap Józef Tokarzewicz-Hodi (Ziołowicz 103). Tak spragniony wspólnoty, z wolna stawał się sam wśród ludzi: „kontakt z otoczeniem utrudniały Norwidowi głuchota, intelektualna wyższość, bujna wyobraźnia, śmiałość skojarzeń, zmysł prowokacji..." (Ziołowicz 103) - czytamy. Bardzo to przygnębiające wyliczenie i nader godne refleksji.

W trzeciej części książki znaleźć można nie mniej niezwykły esej Marii Cieśli-Korytowskiej Karnawat i patos (Cieśla-Korytowska), poświęcony w zasadzie muzyce, a w istocie uroczej formie dowcipnych i bystrych dialogów, w jakie Robert Schumann ujmował swą publicystykę muzyczną. Obszernie przytaczana, odznacza się ona zaskakującą świeżością. W felietonach Schumanna na dwa zmyślone głosy braci o kontrastowych temperamentach, Florestana i Euzebiusza, nieraz znajdowało się miejsce dla propagowania utworów młodzieńczego Chopina, a pisanie to kreśli obraz pełnego werwy, skromnego, przytulnego i życzliwego światu Biedermeieru w złotym wieku niemieckiej kultury muzycznej. Coś z tej bajecznej atmosfery idylli, której niektórzy uczestnicy byli przypadkiem genialni, przeniknęło zdaniem autorki do Promethidiona:

Ewentualny związek formalnych (dialogowość) i merytorycznych pomysłów Norwida $\mathrm{z}$ recenzjami Schumanna z dużym prawdopodobieństwem może być uznany za rezultat znajomości przez polskiego poetę pism Schumanna i samego kompozytora-recenzenta-wydawcy - w końcu dobrego znajomego Norwida i wielbiciela Chopina, niezrażającego się nawet brakiem wzajemności ze strony polskiego muzyka... (Cieśla-Korytowska 255). 
A to wcale nie koniec filiacji i dyfuzji. I choć wszystko to spekulacje w duchu Podróży teatralnej Mickiewicza z Odyńcem Leona Schillera, aż trudno się nie zgodzić, tak wdzięczna to parantela.

Prócz wymienionych, zbiór zawiera też studia: Iwony Puchalskiej „Fraszki", "ruiny" $i$ "vox populi", czyli improwizacja w tekstach Norwida; Piotra Śniedziewskiego "Czarne kwiaty" Norwida $i$ "Une Ombre" Brizeux, czyli od opisu do epifanii; Edyty Żyrek-Horodyskiej Literacki obraz motywu "saisons" w "Jesieni" Cypriana Norwida oraz „To Autumn" Johna Keatsa; Jakuba Czernika Demokracja i równość w twórczości Cypriana Norwida i Walta Whitmana; Małgorzaty Sokalskiej „Wanda" - między misterium a librettem; Edyty Chlebowskiej Szmaragd cesarza Tyberiusza - "prawdziwe" wizerunki Chrystusa w twórczości Norwida; Katarzyny Trzeciak "Gdzie forma z forma mija się i zostawia szpary...". O Norwidowskim widzeniu materialnym; Grażyny Halkiewicz-Sojak "Dwa męczeństwa" - edytorskie i komparatystyczne wejrzenie do poetyckiego laboratorium Norwida; Piotra Chlebowskiego Proces Quidama w świetle rzymskiego prawa; Renaty Gadamskiej-Serafuin Norwid - polski Hafiz?; Olgi Płaszczewskiej Włoskie przekłady poezji Norwida i Agaty Brajerskiej-Mazur O Norwidzie, Niemenie i Bemie komparatystycznie. Wszystkim artykułom należałoby się omówienie bardziej kompleksowe niż ledwie sygnalizująca ich obecność w tomie wzmianka.

Trudno znaleźć takie konteksty i perspektywy, które - zestawione z Norwidem - byłyby produktywne ideowo czy estetycznie. Pisałam już o lekturze negatywnej, wnioskującej z braku faktycznych pokrewieństw ideowych lub genetycznych inspiracji w miejsce domniemanych lub płytkich pokrewieństw. Nie jest to jednak zarzut pod adresem książki, a uwaga ogólna o trudnościach, jakie stawiać musi przed nami czytanie autora Assunty w aktualnym stanie badań. Chwalić można z kolei prezentowany tom za wysoką świadomość specyfiki zadań komparatystycznych i współmierność zestawianych zjawisk. Innymi słowy, dla prezentowanych tu tekstów Norwida oraz innych myślicieli, poetów, ideologów czy twórców teorii da się wskazać tertium comparationis nie bez sensu i powodu. Wykonana przez Siwiec i jej autorów praca zasługuje tym samym na wysoką ocenę merytoryczną.

Bilans omawianego tu cyklu komparatystycznych przybliżeń zarysowuje zaskakującą perspektywę. Poetyka Norwida zarówno w mikrologicznej sferze fenomenologii ekspresji, jak i w kompozycji więcej analogii (dla siebie) znajduje z praktyką dwudziestowiecznej poezji niż z praktyką jego czasu. Więcej łączy na przykład Fortepian Szopena z, powiedzmy, Ziemia jałowa Eliota niż z hugoliańską Legenda wieków. Ciasno obrysowane gesty i zbliżenia, eliminacja komentarzy i technik dygresyjnych na rzecz jukstapozycji - to sposób splatania wątków, jakiego nie znał jeszcze Rimbaud. W poematach Norwida takich jak Quidam czas zmienia się w continuum, gdzie przyczynowa progresja ulega zatarciu. Znika wymiar czasowej głębi: następuje transformacja wyobraźni historycznej w mit. Tak nie pisał nikt w XIX wieku: Norwid jest nieporównany. 


\section{ELIZA KĄCKA, WŚRÓD PORÓWNAŃ I ANALOGII}

\section{BIBLIOGRAFIA}

Baudelaire, Charles. Kwiaty zła. Przeł. Marcin Ciura. Kraków: nakład tłumacza, 2018.

Baudelaire, Charles. Les Fleurs du Mal et poésies diverses. Introd. et notes G. Roth. Paris: Bibliothèque Larousse, 1927.

Cieśla-Korytowska, Maria. „Karnawał i patos”. O Norwidzie komparatystycznie. Red. M. Siwiec. Kraków: Wydawnictwo Uniwersytetu Jagiellońskiego, 2019. S. 241-256.

Kącka, Eliza. „W przedświcie”. Cyprian Norwid, "Klucze od Echa” - Osobność - Wiersze. Wstęp, wybór i oprac. E. Kącka. Kraków: Wydawnictwo Universitas, 2018. S. 9-13.

Kuziak Michał. „Norwid - Marks. Dwie nowoczesności”. O Norwidzie komparatystycznie. Red. M. Siwiec. Kraków: Wydawnictwo Uniwersytetu Jagiellońskiego, 2019. S. 59-75.

Łapiński, Zdzisław. „O «Czułości». Kilka przypisów do Gomulickiego”. O Norwidzie. Rzeczy dawne i najdawniejsze. Lublin: Wydawnictwo KUL, 2014. S. 159-170.

van Nieukerken, Arent. „Norwid i scjentyzm - konteksty komparatystyczne”. O Norwidzie komparatystycznie. Red. M. Siwiec. Kraków: Wydawnictwo Uniwersytetu Jagiellońskiego, 2019. S. 13-57.

Niewczas, Łukasz. „Norwid - parnasista?”. O Norwidzie komparatystycznie. Red. M. Siwiec. Kraków: Wydawnictwo Uniwersytetu Jagiellońskiego, 2019. S. 165-177.

Norwid, Cyprian. Pisma wszystkie. T. 1. Wiersze. Zebrał, tekst ustalił, wstępem i uwagami krytycznymi opatrzył J.W. Gomulicki. Warszawa: Państwowy Instytut Wydawniczy, 1971.

Norwid, Cyprian. „Promethidion”. Dzieła wszystkie. T 4. Poematy 2. Oprac. S. Sawicki, P. Chlebowski. Lublin: Towarzystwo Naukowe Katolickiego Uniwersytetu Lubelskiego Jana Pawła II, 2011.

Rzepczyński, Sławomir. „Norwid, Czadajew i problem europeizacji Rosji”. O Norwidzie komparatystycznie. Red. M. Siwiec. Kraków: Wydawnictwo Uniwersytetu Jagiellońskiego, 2019. S. 77-93.

Siwiec, Magdalena. „Norwid - Baudelaire: profanacje”. O Norwidzie komparatystycznie. Red. M. Siwiec. Kraków: Wydawnictwo Uniwersytetu Jagiellońskiego, 2019. S. 129-146.

Ziołowicz, Agnieszka. „W żywiole towarzyskości. Arkana Norwidowskiej rozmowy”. O Norwidzie komparatystycznie. Red. M. Siwiec. Kraków: Wydawnictwo Uniwersytetu Jagiellońskiego, 2019. S. 195-112.

Żurowski, Maciej. „Norwid i Gautier”. Między renesansem a awangarda: o literaturze europejskiej z perspektywy komparatysty. Warszawa: Wydawnictwo Naukowe PWN, 2007. S. 156-159.

Żurowski, Maciej. „Norwid i symboliści”. Wosiemdziesięciolecie śmierci Cypriana Norwida. Sesja Naukowa Katedry Historii Literatury Polskiej Uniwersytetu Warszawskiego 18-19 grudnia 1963, maszynopis. 